\title{
Cronkhite-Canada syndrome
}

INSERM

\section{Source}

INSERM. (1999). Orphanet: an online rare disease and orphan drug data base. Cronkhite-

Canada syndrome. ORPHA:2930

Cronkhite-Canada syndrome (CCS) is a rare gastrointestinal (GI) polyposis syndrome characterized by the association of non-hereditary Gl polyposis with the cutaneous triad of alopecia, nail changes and hyperpigmentation. 